\section{Prevalence and Potential Impact of Soil- dwelling Pests and Insect Pathogenic Nematodes in Strawberry Fields}

\author{
James A. LaMondia ${ }^{1}$ and Richard S. Cowles \\ The Connecticut Agricultural Experiment Station Valley Laboratory, P.O. Box \\ 248, Windsor, CT 06095
}

Lorraine Los

Plant Science Department, The University of Connecticut, Storrs, CT 06269-4067

Additional index words. black vine weevil, Fragaria $\times$ ananassa, Heterorhabditis

bacteriophora, lesion nematode, Otiorhynchus sulcatus, Pratylenchus penetrans, strawberry

Abstract. Surveys mailed to strawberry growers in 1999 determined the state of nematode and root weevil awareness and practices for their management. Based on the survey response, 41 fields representative of various practices were selected for sampling throughout Connecticut. Adult black vine weevils (Otiorhynchus sulcatus) were found in only 3 fields, but notched leaves characteristic of their feeding were found in 40 fields, indicating a greater prevalence than perceived by growers. The percentage of notched leaves was positively correlated with years in production, suggesting that it took some time for the flightless weevils to migrate into and to increase to damaging numbers in fields. In fields older than 2 years, bifenthrin insecticide reduced leaf feeding compared to untreated fields or to fields treated with endosulfan or azinphos-methyl. Lesion nematodes (Pratylenchus penetrans) were detected in 31 fields and were present in about $58 \%$ of plants. When present, nematode numbers were greater in the margins of poor areas than in adjacent healthy plants (735 vs. 428 per g root, respectively). Lesion nematode numbers were also greater in replanted strawberries than rotated fields (760 vs. 304, respectively). Soil fumigation with methyl bromide, but not methyl dithiocarbamate or the combination of 1,3-dichloropropene and chloropicrin, reduced nematode densities in the following strawberry crop. Based on an economic model, nematodes reduced accumulated profit over 4 fruiting years by more than the percent loss of fruit yield. Beneficial insect pathogenic nematodes, predominantly Heterorhabditis bacteriophora and Steinernema feltiae, were found in $75 \%$ of fields to which commercially obtained nematodes had been applied, and to $14 \%$ of the remaining fields. Presence of naturally occurring insect pathogenic nematodes in strawberry fields may control root weevil populations and lead to more years of productivity.

Acomplex of root diseases and root-feeding insects may be responsible for reduced yield and planting longevity of perennial strawberry (Fragaria $\times$ ananassa Duchesne) in the northeastern U.S. The most important root disease is strawberry black root rot, a debilitating root cortical disease caused by the binucleate fungus Rhizoctonia fragariae Husain and McKeen (Husain and McKeen, 1963; Martin, 1988; Wilhelm and Nelson, 1970; Wilhelm et al., 1972). Rhizoctonia fragariae is commonly associated with perennial strawberry plantings in the Northeast. We consistently isolate it from healthy as well as diseased strawberry roots and it may be assumed to be present at some level in nearly all strawberry plantings. Certain environmental conditions such as drought or waterlogging and root damage by lesion nematodes, Pratylenchus penetrans (Cobb) Filipjev \& Schuurmans Stekhoven, may

Received for publication 19 Jan. 2005. Accepted for publication 3 Mar. 2005. The authors thank J. Canepa-Morrison, Rose Hiskes, Christine Palmer, and S. Lamoureux for technical assistance. This work was supported by Grant LNE98-106, from the Northeast Sustainable Agriculture Research and Education Program.

${ }^{1}$ Corresponding author; e-mailJames.LaMondia@po. state.ct.us. each female. Females then overwinter and can produce more eggs earlier in the summer of their second year(Smith, 1932). Eggs hatch into larvae, which then feed on roots or crowns of strawberry plants. Larval feeding on strawberry roots reduces their biomass and impairs their function, which may be especially injurious if their function has already been compromised by root rot pathogens.

The objectives of this project were to 1) determine current grower perceptions of lesion nematode and root weevil damage, 2) determine the incidence and number of $P$. penetrans per g root, and prevalence of black vine weevil, 3) identify the effects of previous nematode or insect management tactics on nematode or root weevil populations, and 4) determine the presence and species of beneficial insect pathogenic nematodes in commercial strawberry fields in Connecticut.

\section{Materials and Methods}

Grower surveys. Surveys were mailed to commercial strawberry growers in Connecticut in 1999 to determine the perceived importance of damage caused by root weevils and nematodes in their fields and to assess the techniques being used to manage these pests. In total, 72 surveys were mailed and 54 were returned: 24 growers no longer produced strawberries; therefore, 30 surveys were usable.

Field sampling for lesion nematodes and root weevils. Based on the mail survey response, 41 fields were selected for nematode and root weevil sampling. These fields were selected to represent a wide variety of strawberry production practices and included 15 growers, located in 15 towns in 7 (of the 8) counties in Connecticut. Growers participating with the field sampling were interviewed before sampling to determine the cultivar and number of years in production, the prior crop, perceptions concerning damage to strawberry crops resulting from soilborne pests including root weevils and plant parasitic nematodes and control practices for soilborne pests (fumigation, pesticides, rotation, and biological controls). The pest populations found in these fields were correlated with the reported growing practices.

Two methods were used to determine the activity of root weevils during middle to late June 1999 (before renovation). Fields were typically visited between 9:00 AM and 4:00 PM. Two people searched under the strawberry foliage and straw for $5 \mathrm{~min}$ for adult root weevils. In addition, 100 randomly chosen leaves, picked blindly while walking a diagonal transect of the field, were examined for characteristic leaf notching damage, and the resulting percentage was recorded. Leaves counted as having been notched had portions of the margins of the leaves eaten, but did not have holes eaten through the interior of the leaf, which would be typical of adult scarab (Maladera castanea Arrow or Popillia japonica Newman) or leafroller feeding. The effects of insecticide use on percent leaf notching in all fields or in fields older than 2 years were evaluated by ANOVA (NCSS, Kaysville, Utah). Data 
were arcsine transformed before analysis to stabilize variance.

Lesion nematodes were sampled during the weevil evaluation field visit, using six paired samples from good and poor areas of each field (always using the same cultivar for each). Samples from poor areas consisted of low vigor stunted plants taken from the margins of severely affected areas to avoid plants with little or no root system. Good plants were chosen among more vigorous plants growing within $10 \mathrm{~m}$ of poor plants. The overall plant condition varied among sites; therefore, good and poor ratings are relative to each other within a field, and a good plant from one site could have had poorer condition than a poor plant at another site. Entire plants were dug and stored in plastic bags under cool conditions during transport to the laboratory. The six paired samples were later combined to form two composite samples (good vs. poor) from which the nematodes were extracted. Roots were washed free of soil and blotted to remove excess water. Nematodes were extracted from $2 \mathrm{~g}$ of structural and feeder root tissue placed in a flask containing $50 \mathrm{~mL}$ water and shaken for $7 \mathrm{~d}$ using a wrist-action shaker, then counted. The effects of soil fumigation history on nematode numbers per gram fresh shoot weight were compared by Kruskal-Wallis one-way ANOVA and means were separated by the Kruskal-Wallis multiple comparison Z value test (NCSS).

Field sampling for insect pathogenic nematodes. Insect pathogenic nematodes were surveyed from 50 strawberry fields in September 2000 . A composite $200 \mathrm{~mL}$ sample of soil was collected from each field with a flame-sterilized soil probe and then placed in a disposable plastic container, into which five last-instar greater wax moth larvae, Galleria mellonella L. (Grubco, Hamilton, Ohio), were placed (Woodring and Kaya, 1988). The soil and larvae were then kept at ambient room temperature, and the larvae were checked at 4 and $7 \mathrm{~d}$ for nematode infection. Larvae showing characteristic signs of nematode infection (involving death, discoloration, and nematodes being visible through the insect's cuticle) were removed, rinsed, and placed individually on moist filter paper within a petri dish. Emerging infective juvenile stage nematodes were rinsed from the filter paper and measured (length, width, head and tail) to assign them to species based on morphometric tables (Nguyen and Smart, 1996).

\section{Results and Discussion}

Grower surveys. The 30 usable surveys represented about 200 acres of strawberry fields ( $>70 \%$ of Connecticut strawberry production). In 1999, the Connecticut Department of Agriculture estimated a total of 278 strawberry acres in Connecticut (R. Macsuga, personal communication). Half of the growers surveyed had $<5$ acres in strawberry production, $30 \%$ grew between 5 and 10 acres, and 20\% grew $>10$ acres of strawberries.

Only $24 \%$ of growers perceived root weevils to be frequently or severely damaging,
$36 \%$ responded that root weevils were rarely damaging, and $40 \%$ indicated that they were unimportant or were unaware of damage. Most weevils and $62 \%$ did not apply insecticides for weevil control. Those that did apply insecticides for root weevil control used bifenthrin (Brigade), azinphos-methyl (Guthion), or endosulfan (Thiodan). Only one grower had applied insect pathogenic nematodes for root weevil control. Of the growers, $76 \%$ used pesticides for other insect and mite control. The most frequently used insecticides were azinphos-methyl and endosulfan.

Grower perception of nematode damage was similar to their views on root weevils. Only $25 \%$ indicated that nematodes were frequently or severely damaging, $25 \%$ responded that nematodes were rarely damaging, and 50\% indicated that they were unimportant or were unaware of damage. Most growers (80\%) had not previously sampled for nematodes. Of those that had, lesion nematodes were the dominant nematode reported. In total, $23 \%$ of growers had fumigated fields, $10 \%$ with methyl bromide, $10 \%$ with methyl dithiocarbamate (Vapam), and $3 \%$ with the combination of 1,3-dichloropropene and chloropicrin (Telone). Eighty percent of growers had not used carbofuran (Furadan) or fenamiphos (Nemacur) within the last 5 years. Most growers indicated that they rotated fields out of strawberry production growers $(70 \%)$ did not monitor fields for root

for 2 to 3 years and planted a wide variety of crops in the intervening years.

Field sampling for lesion nematodes and root weevils. Adult black vine weevils were the only species of root weevil adult found, and were only recovered from 3 of 41 fields during the 5-min timed searches $(1,2$, and 4 weevils found in fields with $37 \%, 92 \%$, and $82 \%$ leaf notching, respectively). However, notched leaves, presumably resulting from weevil feeding, were found in 40 fields (Fig. 1). Of the sampled fields, $33(80 \%)$ had $<50 \%$ leaf notching. Eight of the 41 fields $(20 \%)$ had $>50 \%$ of sampled leaves with leaf notching, representing populations that presumably would lead to economic injury. The $20 \%$ of fields with $>50 \%$ leaf notching might be suspected to correspond to the perception of $24 \%$ of growers that found root weevils to be damaging. However, of the six growers with highly infested fields ( $>50 \%$ leaf notching), five either did not recognize or did not know whether root weevils were important in their fields. Three growers with fields that experienced relatively little leaf notching recognized the damage potential of root weevils. Their survey responses may not represent misclassification of field conditions, because two of the three had applied insecticide to control weevils (which might otherwise have had higher percentage leaf notching). These results indicate that root weevils are very common in

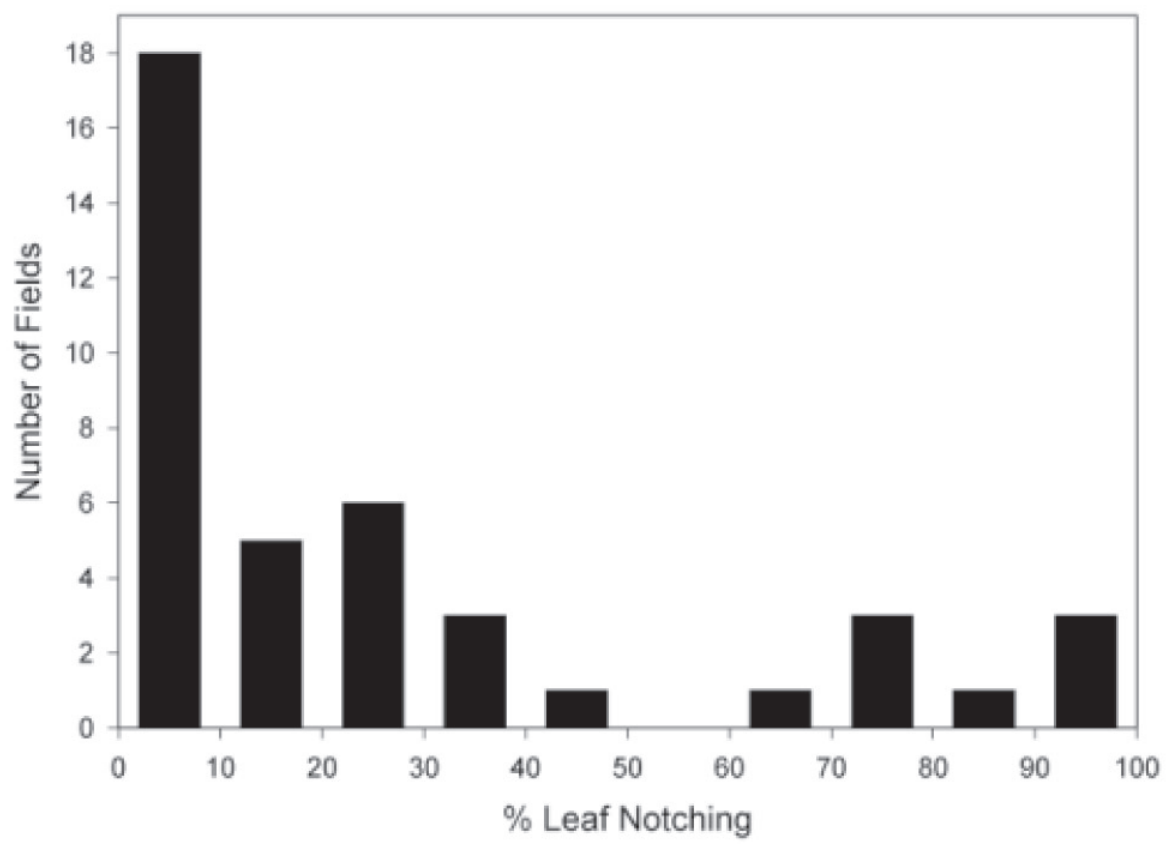

Fig. 1. Histogram of the number of strawberry fields, out of 41 fields surveyed in Connecticut, classified by the percentage of leaf notching from a 100-leaf sample collected during the strawberry harvest. Leaf notching was presumed to have been caused by adult root weevils (Otiorhynchus spp.). Note that in the $0 \%$ to $10 \%$ leaf notching category, only one field was found with no leaf notching.

Table 1. The effects of insecticide application on strawberry leaf notching due to Otiorhynchus sulcatus.

\begin{tabular}{lcc}
\hline & \multicolumn{2}{c}{ Leaf notching $(\%)^{\mathrm{z}}$} \\
\cline { 2 - 3 } Insecticide & All strawberry fields & Fields older than 2 years \\
\hline None & 29.6 & $40.7 \mathrm{ab}$ \\
Thiodan (endosulfan) or Guthion (azinphos-methyl) & 29.2 & $78.2 \mathrm{~b}$ \\
Brigade (bifenthrin) & 9.8 & $27.0 \mathrm{a}$ \\
$P$ & 0.49 & 0.05 \\
\hline
\end{tabular}

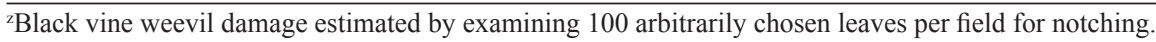


commercial perennial strawberry fields and are a greater problem than was perceived by most growers.

The percentage of notched leaves was highly correlated with years of strawberry production $(r=0.72, P=0.001)$, indicating that it took some time for the flightless weevils to migrate into strawberry fields and increase in number. The extent of leaf notching was not correlated with the use of insecticides, except for fields older than 2 years (Table 1). In these older fields, bifenthrin (Brigade) insecticide reduced leaf notching compared to fields treated with endosulfan (Thiodan) or azinphosmethyl (Guthion) $(P=0.05)$. Endosulfan and azinphos-methyl are now practically non-toxic to black vine weevil and may instead reduce the populations of beneficial predators (Çilgi et al., 1996; Cowles, 1997; Evenhuis, 1982). There were no differences in leaf notching as a result of rotation or with different strawberry cultivars.

The use of leaf notching as a measure of root weevil activity was a necessary, though somewhat inconclusive, substitute for direct assessments of weevil populations through trapping or direct observation. The benefit of using leaf notches is that the feeding activity of weevils leaves a cumulative record, and the amount of foliage consumed should be roughly proportional to the number of eggs

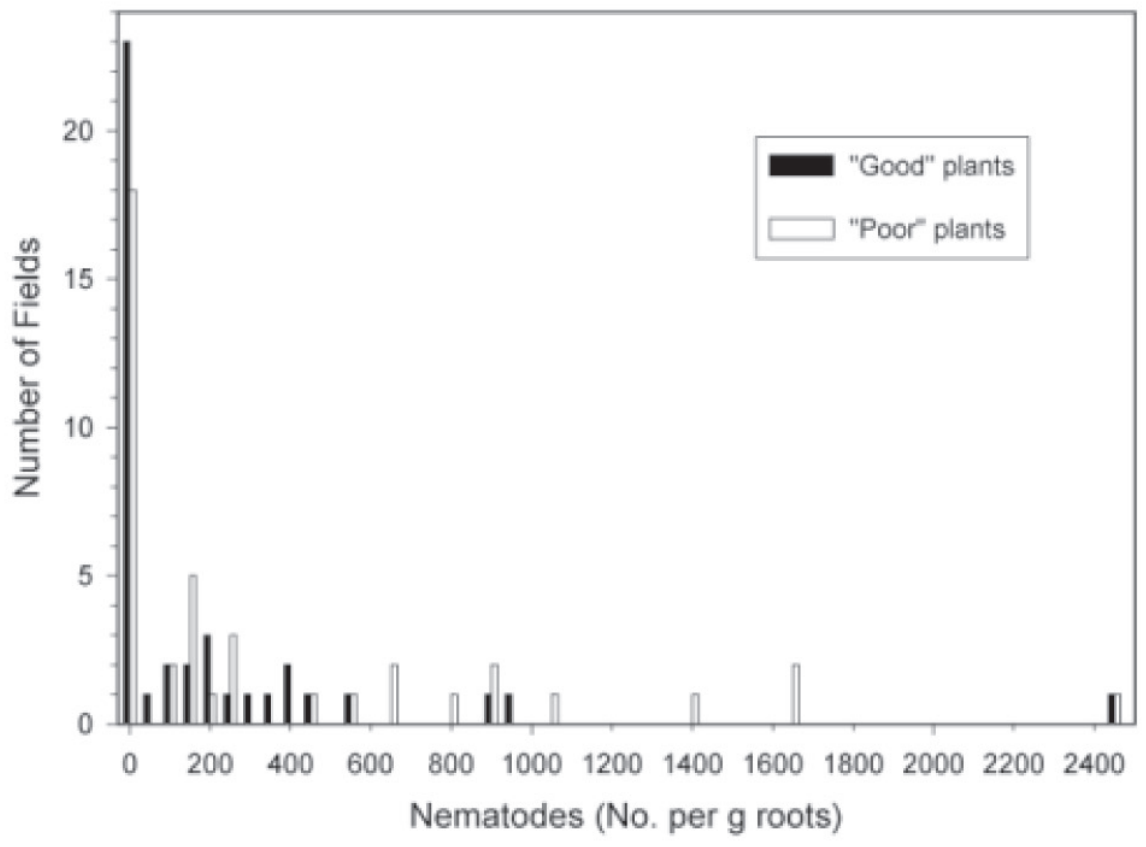

Fig. 2. Histogram of the number of strawberry fields, out of the 41 fields surveyed in Connecticut, classified by the number of lesion nematodes recovered from samples of roots from plants taken from paired good and nearby poor plants. Fields varied in vigor so the classification of good and poor was relative within each field.

Table 2. The effects of preplant soil fumigation on lesion nematode (Pratylenchus penetrans) density in strawberry roots.

\begin{tabular}{lc}
\hline Fumigant & $\begin{array}{c}\text { P. penetrans } \\
\text { (per g root) }^{\mathbf{z}}\end{array}$ \\
\hline None & $357 \mathrm{~b}$ \\
Vapam (metam sodium) or Telone (1,3-dichloropropene) & $420 \mathrm{~b}$ \\
Methyl bromide & $8.8 \mathrm{a}$ \\
$P$ & 0.0006 \\
\hline
\end{tabular}

${ }^{ } \mathrm{Nematodes}$ were extracted from $2 \mathrm{~g}$ of structural and feeder root tissue placed in a flask containing $50 \mathrm{~mL}$ water and shaken for $7 \mathrm{~d}$ using a wrist-action shaker, then counted. and straw used in strawberry culture provides very abundant daytime refuges that compete with board traps.

This field survey resulted in poorer recovery of adult weevils using the 5-min timed search method than a previous field study in strawberries, which averaged 4.3 live weevils per timed sample (Cowles, 1997). Several factors may be involved in the poor recovery of weevils. Our sampling was conducted in the daytime, during drought conditions, and the weevils may already have completed their preovipositional period. All three factors may have resulted in weevil adults entering the soil rather than remaining accessible at the soil surface.

Lesion nematodes were detected in 31 of 41 fields and were present in similar proportions in good or poor plants, $59 \%$ and $56 \%$, respectively (Fig. 2). When present, nematode numbers were greater $(P=0.01$, Wilcoxon signed rank test) in the margins of poor areas than in more vigorous adjacent good plants of the same cultivar ( 735 vs. 430 per g root, respectively). Lesion nematode numbers were also present in greater numbers in replanted strawberries than when fields had been rotated away from strawberry (760 vs. 304 , respectively; $P=0.03$ ). The average rotation away from strawberries was for 2 years and a wide variety of plants were grown including corn, pumpkins, small grains, sudangrass and vegetables. Soil fumigation with methyl bromide, but not methyl dithiocarbamate(Vapam) or 1,3 dichloropropene plus chloropicrin (Telone) reduced nematode densities in the following strawberry crop $(P=0.05)$ (Table 2$)$.

Grower perceptions about, versus the reality of, the prevalence of nematodes in their fields can be summarized as follows: four growers felt that nematodes were not a problem, which agreed with their field conditions. Three out of four of these growers fumigated before planting strawberries, two with methyl bromide and one with Telone. Two of the three growers that acknowledged nematodes to be damaging fumigated soil with Vapam before planting, yet still ended up with damaging populations. The remaining eight growers either did not know about or did not think that damaging nematode populations were present, did not apply fumigants, and had injurious nematode populations.

Lesion nematodes and root-feeding insects each impact perennial strawberry production in the northeastern U.S. The resulting decline in plant vigor and fruit yield shortens the productive life of a perennial planting, often by several years. The loss of a fruiting year and additional costs required during replanting have a dramatic negative impact on economic return (DeMarree and Rieckenberg, 1998). The regression between lesion nematode populations and strawberry yield (LaMondia, 1999) was used to predict fruit yield losses from fruiting year two to four. Strawberry fruit weight was best correlated with nematode densities one year before harvest (LaMondia, 1999). The resulting percent reduction in profits was calculated using an economic model (DeMarree and Rieckenberg, 1998) with fruit yield as an input. Accumulated profit is presented in Table 
Table 3. The effects of initial lesion nematode (Pratylenchus penetrans) density in roots on strawberry yield and accumulated profit over four fruiting seasons.

\begin{tabular}{llcccc}
\hline $\begin{array}{l}\text { Nematode density } \\
\text { (no./g root) }\end{array}$ & \multicolumn{3}{c}{ Strawberry yield (qt/acre) } & Accumulated \\
\cline { 2 - 5 } & Year 1 & Year 2 & Year 3 & Year 4 & profit (\$) (loss) \\
\hline 0 & 7000 & 7000 & 4000 & 3000 & 7699 \\
50 & $6279^{\mathrm{y}}$ & 6279 & 3588 & 2691 & 5205 \\
100 & 5565 & 5565 & 3180 & 2385 & 2795 \\
150 & 4844 & 4844 & 2768 & 2076 & 360 \\
200 & 4130 & 4130 & 2360 & 1771 & $(2049)$ loss \\
250 & 3409 & 3409 & 1948 & 1461 & $(4484)$ loss \\
300 & 2695 & 2695 & 1540 & 1155 & $(6895)$ loss \\
\hline
\end{tabular}

${ }^{2}$ Accumulated profit or loss over preplant, planting year and 4 fruiting years based on annual crop yields using an economic model and 1996 expense and crop value data (DeMarree and Rieckenberg, 1998).

${ }^{y}$ Yield reductions determined from the regression of initial nematode density in roots with strawberry fruit yield data (LaMondia, 1999).

3. Initial lesion nematode densities of $50 / \mathrm{g}$ root reduced yield by $10.3 \%$ and reduced accumulated profit by $32.4 \%$ over the 4 fruiting years of the planting. The accumulated fixed and variable costs of producing the crop over that time increase the loss in profit to beyond the percentage of annual fruit yield loss due to the pestalone. Initial lesion nematode densities of 100,150 , and $200 / \mathrm{g}$ root reduced yield by $20.5 \%, 30.8 \%$, and $41.0 \%$ respectively, but reduced accumulated profit by $63.7 \%, 95.3 \%$, and $>100 \%$, respectively. The decline in yield experienced in these scenarios and resulting economic losses would likely result in the early removal and replanting of the crop. Lesion nematode impact on the strawberry crop was likely much larger than perceived by growers in the presampling survey.

The losses due to initial lesion nematode densities presented in Table 3 assume uniform distribution of nematodes in every root of every plant within the field. This obviously does not occur. Nematode damage typically occurs in clumped distribution seen as elliptical patches throughout the field. As a result, actual fruit yield occurs as a patchwork of good and poor areas. The average nematode density reported from plant sampling is a reflection of both number per plant and the number (or proportion) of affected plants sampled. Nematode densities in individual infected plants are often much higher than the 0 to 300/g root used in Table 3, especially when they are sampled in the fall (LaMondia, 2002). These damaged areas slowly increase in size and number over the years.

Strawberry fields with a large number of areas heavily infested with lesion nematodes often decline in a manner similar to the scenarios presented in Table 3 and may be removed prematurely from production at a loss to the grower. This may be due to nematode infection alone, or more likely, to the interaction of lesion nematodes with $R$. fragariae to result in severe strawberry black root rot. Injury or stress to strawberry root tissue is important for increasing infection by $R$. fragariae. It appears that $R$. fragariae commonly resides on the sloughed cortex of healthy perennial roots (LaMondia, 2003; Wilhelm and Nelson, 1970; Wilhelm et al., 1972). From any source of inoculum, the fungus may infect structural or feeder roots, especially when the plant is under stress or roots are damaged by lesion nematodes. Nematode feeding and movement result in direct cortical cell damage and death and indirectly result in discoloration of the endodermis and early polyderm formation, followed by localized areas of secondary growth initiation in structural roots and cortical cell weakening or death (LaMondia, 2003, 2004; Townshend, 1963; Zunke, 1990). Weakened or dying cells resulting from the direct or indirect effects of $P$. penetrans are more susceptible to $R$. fragariae, thereby increasing infection and cortical root rot.

Wing et al. (1995) surveyed growers and conducted correlations between physical, cultural and biotic factors and strawberry black root rot. Their survey and evaluations did not evaluate root weevils or any other insect pest of strawberry. Their results demonstrated a weak positive correlation between the population density of lesion nematodes in soil and root health, but failed to find any correlation between populations in roots and disease. These counterintuitive results may be related to their sampling techniques and the fact that these obligate plant parasites require living root tissue upon which to feed. By sampling at the edge of affected areas of strawberry fields in the present study, we were able to associate plant damage with larger numbers of nematodes in plant roots.

Field sampling for insect pathogenic nematodes. Insect pathogenic nematodes were recovered from $11(22 \%)$ of the growers' fields. Species most commonly collected were morphologically matched to Heterorhabditis bacteriophora and Steinernema feltiae, from nine and three fields, respectively. Nematodes resembling $S$. carpocapsae were recovered from one field. In 2000, five growers applied insect pathogenic nematodes to fields; nematodes were recovered from four out of six $(75 \%)$ of the treated fields. In one case, the grower had applied $S$. feltiae; both $S$. feltiae and $H$. bacteriophora were recovered from that field.

We recovered insect pathogenic nematodes from 6 fields that had never been treated with nematodes (14\% of those fields), and one species was recovered that had not been applied in a nematode-treated field. On three farms, we have recovered insect pathogenic nematodes from fields that were moderately infested with black vine weevil, but had remained productive for an unusually long time ( 7 to 9 years). In both strawberry plantings and field grown nursery crops, the collapse of black vine weevil populations in their boom-and-bust dynamics commonly appears to be associated with epizootics of insect pathogenic nematodes. Up to four different species of insect pathogenic nematodes have been collected in single locations where these epizootics have occurred in Connecticut, suggesting that native or naturalized insect pathogenic nematode populations are very common, and that outbreaks of root weevil populations provide an excellent opportunity for amplification of these nematode populations to an extent that they easily can be collected (R. Cowles, unpublished). These observations suggest that introduction of insect pathogenic nematodes early in a crop cycle, perhaps one year after planting, might permit root weevils to reach a low, nondamaging equilibrium population without having to proceed through an explosive growth phase that damages strawberry plants.

Strawberries with healthy root systems can easily sustain two or more root weevil larvae without a reduction in yield or quality of berries (Penman and Scott, 1976). Such a high economic threshold suggests that biological control through the use of insect pathogenic nematodes is a sensible strategy. As we observed in certain fields with naturally occurring nematode populations, root weevils appeared to be maintained at nondamaging populations for a number of years. Injury to strawberry plants from root disease may play an important part in disturbing a favorable balance of strawberry roots, root weevils, and insect pathogenic nematodes. As noted by Cram (1978), tolerance of strawberries to larval root weevil feeding is governed by the ability of the plant to regrow roots. If this ability is compromised by root disease, then root weevil feeding on already weakened root systems will result in plant decline. Therefore, under conditions where root disease is present, the economic threshold for root weevil larvae would be lower than two larvae per plant, and insect pathogenic nematodes may not sustain themselves well or be able to maintain such low population densities of weevils.

Overall, strawberry growers in Connecticut were not well aware of the extent to which soildwelling organisms were affecting the health of their plantings. Although black vine weevils, and probably other root weevils, were present in nearly all strawberry fields, this pest complex is manageable through well-timed insecticide and insect pathogenic nematode applications. A greater concern is the continued impact of lesion nematodes and the associated black root rot on the health of perennial strawberry plantings. Fields suitable for pick-your-own marketing are in limited supply, which favors short rotations between strawberry plantings. Short between-crop rotations favor the carryover of lesion nematode and other root disease inoculum, unless the fields are effectively fumigated. Based on our survey results, the only highly effective fumigant for lesion nematode population reduction was methyl bromide. Once this product is no longer available, growers will need to reevaluate their other management approaches to minimize plant parasitic nematode populations. 


\section{Literature Cited}

Chen, T.A. and A.E. Rich 1962. The role of Pratylenchus penetrans in the development of strawberry black root rot. Plant Dis. Rptr. 46:839-843.

Çilgi, T., S.D. Wratten, J.L. Robertson, D.E. Turner, J.M. Holland, and G.K. Frampton. 1996. Residual toxicities of three insecticides to four species (Coleoptera: Carabidae) of arthropod predator. Can. Entomol. 128:1115-1124.

Cowles, R.S. 1997. Several methods reduce insecticide use in control of black vine weevils. Frontiers Plant Sci. 49(2):2-4.

Cram, W.T. 1978. The effects of root weevils (Coleoptera: Curculionidae) on yield of five strawberry cultivars in British Columbia. J. Entomol. Soc. B.C. $75: 10-13$.

DeMarree, A.M., and R. Rieckenberg. 1998. Strawberry profit spreadsheet template. In: M. Pritts and D. Handley (eds.). Strawberry production guide. NRAES-88. N.E. Reg. Agr. Eng. Serv., Ithaca, N.Y.

Evenhuis, H.H. 1982. Control of the black vine weevil Otiorrhynchus sulcatus (Coleoptera: Curculionidae). Med. Fac. Landbouww. Rijkesuniv. Gent 47:675-678.

Goheen,A.C. and J.S. Bailey. 1955. Meadow nematodes in strawberry plantings in Massachusetts. Plant Dis. Rptr. 39:879-880.

Goheen, A.C. and J.B. Smith. 1956. Effects of inoculation of strawberry roots with meadow nematodes, Pratylenchus penetrans. Plant Dis. Rptr. 40:146-149.

Hesjedal, K. 1984. Influence of nitrogen content in strawberry leaves on the fecundity of the vine weevil, Otiorhynchus sulcatus F. (Coleoptera: Curculionidae). Acta Agr. Scand. 34:188-192.

Husain, S.S. and W.E. McKeen. 1963. Interactions between strawberry roots and Rhizoctonia fragariae. Phytopathology 53:541-545.

LaMondia, J.A. 1994. The association of lesion nematodes with black root rot in strawberry fields.
NE-SARE Small Fruits Nwslt. 4:10-11.

LaMondia, J.A. 1999. The effects of Pratylenchus penetrans on strawberry vigor and yield. J. Nematol. 31:418-423.

LaMondia, J.A. 2002. Seasonal populations of lesion and root-knot nematodes in strawberry roots. J. Nematol. 34:409-413.

LaMondia, J.A. 2003. The interaction of Pratylenchus penetrans and Rhizoctonia fragariae in strawberry black root rot. J. Nematol. $35: 17-22$.

LaMondia, J.A. 2004. Strawberry black root rot. In: Advances in strawberry research (in press).

LaMondia, J.A. and S.B. Martin. 1989. The influence of Pratylenchus penetrans and temperature on black root rot of strawberry by binucleate Rhizoctonia spp. Plant Dis. 73:107-110.

Maas, J.L. 1998. Compendium of strawberry diseases. 2nd ed. Amer. Phytopathol. Soc., St. Paul, Minn.

Maier, C. 1978. Dispersal of adults of the black vine weevil, Otiorhynchus sulcatus (Coleoptera: Curculionidae), in an urban area. Environ. Entomol. 7:854-857.

Maier, C. 1986. Relative abundance of adults of Callirhopalus bifasciatus (Roelofs) and three Otiorhynchus spp. (Coleoptera: Curculionidae) on certain cultivated and wild plants in Connecticut. J. N.Y. Entomol. Soc. 94:70-77.

Martin, S.B. 1988. Identification, isolation frequency, and pathogenicity of anastomosis groups of binucleate Rhizoctonia spp. from strawberry roots. Phytopathology 78:379-384.

Masaki, M., K. Ohmura, and F. Ichinohe. 1984 Host range studies of the black vine weevil, Otiorhynchus sulcatus (Fabricius) (Coleoptera: Curculionidae). Appl. Entomol. Zool. 19:95-106.

Nguyen, K.B. and G.C. Smart, Jr. 1996. Identification of entomopathogenic nematodes in the Steinernematidae and Heterorhabditidae (Nemata: Rhabditida). J. Nematol. 28:286-300.
Penman, D.R. and R.R. Scott. 1976. Impact of black vine weevil, Otiorhynchus sulcatus (F.), on blackcurrants and strawberries in Canterbury. N.Z. J. Expt. Agr. 4:381-389.

Schloemann, S. 2002. New England small fruit pest management guide. Univ. Mass. Ext.

Shanks, Jr., C.H. and R.P. Doss. 1986. Black vine weevil (Coleoptera: Curculionidae) feeding and oviposition on leaves of weevil-resistant and -susceptible strawberry clones presented in various quantities. Environ. Entomol. 15:1074-1077.

Smith, F.F. 1932. Biology and control of the black vine weevil. U.S. Dept. Agr. Tech. Bul. 325:1-45.

Townshend, J.L. 1963. The pathogenicity of Pratylenchus penetrans to strawberry. Can. J. Plant Sci. 43:75-78.

Warner, R.E. and F.G. Negley. 1976. The genus Otiorhynchus in America north of Mexico. Proc. Entomol. Soc. Wash. 78: 240-262.

Wilhelm, S. and P.E. Nelson. 1970. A concept of rootlet health of strawberries in pathogen-free soil achieved by fumigation. Pp. 208-215 In: T.A. Toussoun, R.V. Bega, and P.E. Nelson (eds.). Root diseases and soilborne pathogens. Univ. Calif. Press, Berkeley.

Wilhelm, S., P.E. Nelson, H.E. Thomas, and H. Johnson. 1972. Pathology of strawberry root rot caused by Ceratobasidium species. Phytopathology 62:700-705.

Wing, K.B., M.P. Pritts, and W.F. Wilcox. 1995. Biotic, edaphic and cultural factors associated with strawberry black root rot in New York. HortScience 30:86-90.

Woodring, J.L. and H.K. Kaya. 1988. Steinernematid and heterorhabditid nematodes, A handbook of techniques. Ark. Agr. Expt. Sta., Fayetteville, S. Coop. Ser. Bul. 331.

Zunke, U. 1990. Observations on the invasion and endoparasitic behavior of the root lesion nematode Pratylenchus penetrans. J. Nematol. 22:309-320. 